\title{
The Failure of the International Community to Apply R2P and Atrocity Prevention in Myanmar
}

\author{
Martin Mennecke \\ Associate Professor, Department of Law, University of Southern Denmark, \\ Odense, Denmark \\ marme@sam.sdu.dk \\ Ellen E. Stensrud \\ Senior Researcher and Project Coordinator, The Norwegian Center \\ for Holocaust and Minority Studies, Oslo, Norway \\ ellen.stensrud@hlsenteret.no
}

\begin{abstract}
The case of Myanmar has become one of the most glaring examples for the failure of the international community to realise the promise made with the adoption of the responsibility to protect $\left(\mathrm{R}_{2} \mathrm{P}\right)$ norm in 2005: 'Never again' has turned into again and again. A mix of unwillingness and inability to prevent atrocity crimes has in Myanmar over the past ten years led to several instances of atrocity crimes and genocidal violence against the Rohingya. Most recently, the military coup of February 2021 has showcased that the notion of an international community exercising a responsibility to protect the population of Myanmar against crimes against humanity and other atrocity crimes dissembles into a few states openly shielding the perpetrators, a few condemning and countering the newest cycle of violence, and many silent bystanders to the ongoing atrocities. This article discusses the role of the $\mathrm{R}_{2} \mathrm{P}$ norm in the case of Myanmar and introduces the different contributions that comprise the special issue on Myanmar and the failure of $\mathrm{R}_{2} \mathrm{P}$.
\end{abstract}

\section{Keywords}

responsibility to protect - Myanmar - Rohingya - international community 
In August 2017, one of the most severe human rights catastrophes of our time played out as the Myanmar military committed mass atrocities against the Rohingya minority, forcing more than 700,00o Rohingya to flee the country. The horrific crimes against the Rohingya were committed in a period in which Myanmar had opened up to the outside world - yet outside actors did little to prevent the atrocities. This special issue seeks to explain why outside actors failed to deliver on the promise of atrocity prevention, despite of the commitment these same actors have made to the responsibility to protect $\left(\mathrm{R}_{2} \mathrm{P}\right)$. Contributions look at the role of Western governments, regional actors, and legal mechanisms. The special issue also presents two practitioners' perspectives on the challenges of implementing $\mathrm{R}_{2} \mathrm{P}$ in Myanmar.

This introduction will provide a short background on the situation of the Rohingya population in Myanmar and the political context in which the atrocities took place. Furthermore, it will highlight key questions and issues regarding the application of responsibility to protect to this situation. As a first step we will situate the special issue and its articles in regard to the recent military coup. In the final section, we will briefly present the focus of the different contributions to the special issue.

On 1 February 2021, the Myanmar military (known as the Tatmadaw) dramatically altered the course of the country. By overthrowing the civilian government, the Tatmadaw dashed the fragile hopes that Myanmar was slowly transitioning towards a democratic future. Instead, the military reasserted full control and ordered a state of emergency. In an inspiring, brave act of resistance, initially hundreds of thousands of Myanmar's citizens took to the streets to protest against the coup, defying the security forces' brutal, deadly response to the peaceful demonstrations. Two months into the coup, the protests continue on a smaller scale, with thousands staging strikes as an expression of their opposition to the military. At the time of writing, the death toll approaches 700 and more than 3,00o have been detained or were unaccounted for.

The international response to these developments has been mixed. ${ }^{1}$ The UN Secretary-General and numerous countries condemned the military takeover, with the United States, the European Union and the United Kingdom issuing sanctions against the military leadership and their economic interests. At the

1 For an intial overview see International Crisis Group, 'Responding to the Myanmar Coup', Briefing No. 166, 16 February 2021, https://www.crisisgroup.org/asia/south-east-asia/myanmar/ b166-responding-myanmar-coup, accessed 16 March 2021. 
United Nations (UN), however, different views persisted, and the UN Security Council could not unite behind a statement clearly condemning the coup, not to mention pass an actual resolution, setting out a concrete response to the increasing security risks and the gross human rights violations. ${ }^{2}$ At the UN Human Rights Council, a special session was called as a reaction to the events, and the Human Rights Council did adopt two resolutions - but it did not authorise any new measures besides requesting the UN Special Rapporteur on Human Rights in Myanmar and the Office of the High Commissioner for Human Rights to do what would seem self-evident, i.e. to monitor and report on the new situation. ${ }^{3}$ Within the region and ASEAN, the response was even more muted, as countries such as Thailand, Cambodia, and Vietnam have refused to criticise the coup, referring to it as an internal matter. ${ }^{4}$

What is the significance of $\mathrm{R}_{2} \mathrm{P}$ for Myanmar in the current situation? Neither the Security Council nor the Human Rights Council referred in their responses to R2P. Only very few UN member states did. ${ }^{5}$ In fact, it took the UN Office on Genocide Prevention and the Responsibility to Protect until almost two months after the coup to issue a public statement to remind states of the importance of $\mathrm{R}_{2} \mathrm{P}$ under the current circumstances. ${ }^{6}$ Almost ironically, and sadly, the only actor to explicitly invoke $\mathrm{R}_{2} \mathrm{P}$ are members of the anti-coup

2 The UN Security Council could only agree to a non-binding presidential statement (S/PRST/2O21/5, 10 March 2021, https://undocs.org/S/PRST/2021/5, accessed 11 April 2021). On 1 April, when the situation in Myanmar had escalated further, the Council issued new press elements (available at https://myanmar.un.org/en/123792-un-security-council-press-elementsmyanmar), and on 9 April it held on the initiative of a number of Western members a public meeting on Myanmar under the Arria Formula which also allowed civil society and UN member states outside the Council to speak. Regardless, the Council continued to fail to take any concrete measures to address the situation.

3 For the special session and the first resolution adopted by the UN Human Rights Council see the dedicated website at https://www.ohchr.org/EN/HRBodies/HRC/SpecialSessions/ Session29/Pages/29thSpecialSession.aspx, accessed 16 March 2021. The resolution strongly condemning the coup and detailing new tasks for the UN Special Rapporteur and the UN High Commissioner for the Human Rights is contained in A/HRC/46/L.21, 16 March 2021 (see paras. 1 and $48-53)$.

4 On the different views within ASEan see 'ASEAN Urges Peaceful Solution to Myanmar Coup Standoff', VOA News, 2 March 2021, https://www.voanews.com/east-asia-pacific/asean-urgespeaceful-solution-myanmar-coup-standoff, accessed 16 March 2021.

5 See, for example, the Joint Nordic Statement by Denmark, Finland, Iceland, Norway and Sweden at the UN Security Council for the Arria Formula Meeting on Myanmar, 9 April 2021, https://fnnewyork.um.dk/en/news-from-the-mission/newsdisplaypage/?newsID=5Coo63D1B474-4846-A889-oEE68920945B, accessed 11 April 2021.

6 Joint Statement by UN Special Adviser on the Prevention of Genocide and the UN High Commissioner for Human Rights on Myanmar, 28 March 2021, https://www.un.org/sg/ en/content/note-correspondents-joint-statement-un-special-adviser-the-prevention-ofgenocide-and-un-high-commissioner-for-human-rights-myanmar, accessed on 11 April 2021. 
movement, who during their demonstrations in the streets of Myanmar repeatedly have called for $\mathrm{R}_{2} \mathrm{P}$ to be implemented. ${ }^{7}$

From an $\mathrm{R}_{2} \mathrm{P}$ perspective, the post-coup situation in Myanmar calls for new atrocity prevention efforts to reflect the increased atrocity risks on the ground. After all, it is the Tatmadaw that has forced its way back to full control - the same Tatmadaw that represents a history of violence and impunity and bears responsibility for widespread atrocities across the country, committed against various ethnic groups, including the Rohingya. Situations of upheaval, including military coups, are one of the paradigmatic risk factors listed in the UN Framework of Analysis of Atrocity Crimes. ${ }^{8}$ Indeed, the persisting resistance of large parts of the civilian population against the coup makes them the potential target of new atrocities. Moreover, atrocity prevention makes it necessary to consider and prepare for scenarios that see a further escalation of the current violence. ${ }^{9}$ This could include new clashes between the Tatmadaw and ethnic armed groups in certain parts of the country (with a high impact on the civilian population), or confrontations between the military and armed protesters, which could see support by several of the ethnic armed groups. In another scenario, the military might turn against the remaining Rohingya in Rakhine State, seeking to distract from the protests and the coup.

$\mathrm{R}_{2} \mathrm{P}$ proponents, therefore, have to ensure that their responses to the military coup include an atrocity prevention lens instead of focusing on the question of restoring the democratically elected government. In this regard it was striking that the initial Western responses to the coup centred exclusively around the release of State Counsellor Aung San Suu Kyi and other politicians and did not address the looming threat of new atrocities against the civilian

7 These calls may not always reflect a technically correct understanding of the $\mathrm{R}_{2} \mathrm{P}$ norm but put emphasis on the idea of an international military intervention to stop the coup. See, for example, Caleb Quinley, 'More Protesters in Myanmar Call for Armed Intervention as Crackdown Intensifies', Vice, 9 March 2021, https://www.vice.com/en/article/z3vdya/moreprotesters-in-myanmar-call-for-armed-intervention-as-crackdown-intensifies, accessed 16 March 2021. The local, popular calls for $\mathrm{R}_{2} \mathrm{P}$ still serve as a powerful reminder of the basic protection message behind $\mathrm{R}_{2} \mathrm{P}$ - and show that $\mathrm{R}_{2} \mathrm{P}$ and this message, opposite what some critics might suggest, continue to have universal resonance and meaning.

8 United Nations, Framework of Analysis for Atrocity Crimes: A Tool for Prevention (New York: United Nations, 2014), p. 10, https://www.un.org/en/genocideprevention/documents/atrocitycrimes/Doc.49_Framework\%20of\%2oAnalysis\%2ofor\%20Atrocity\%2oCrimes_EN.pdf, accessed 16 March 2021.

9 International Crisis Group, 'The Cost of the Coup: Myanmar Edges Towards State Collapse', Briefing No. 167, 1 April 2021, https://www.crisisgroup.org/asia/south-east-asia/myanmar/b167cost-coup-myanmar-edges-toward-state-collapse, accessed 1o April 2021. 
population. ${ }^{10}$ States committed to $\mathrm{R} 2 \mathrm{P}$ need to analyse the situation to identify new atrocity risks, potential triggers and targets among the population, and initiate suitable preventative measures.

While the military coup has renewed the threat of mass atrocities in Myanmar, this special issue focuses on the international failure to protect the Rohingya against genocidal atrocities back in 2017. How was it possible that thousands were killed, mutilated, and raped and hundreds of thousands forced to flee to neighbouring Bangladesh despite of the often-cited consensus around $\mathrm{R}_{2} \mathrm{P}$ ? What does $\mathrm{R}_{2} \mathrm{P}$ mean in practice, when applied to a country situation? What difference does it make compared to other prevention or mitigation efforts? The need to reflect on the practical meaning and significance of $\mathrm{R}_{2} \mathrm{P}$ is all the more urgent, as the mass atrocities against the Rohingya in 2017 had been the subject of numerous prior warnings. The writing was not merely on the wall, but all over the wall.

Already in 2010, a report by the Irish Centre for Human Rights warned that crimes against humanity were being committed against the Rohingya. ${ }^{11}$ After the violence in 2012, which mainly targeted Rohingya in Rakhine State, Human Rights Watch (HRW) found that although much of the violence took the form of sectarian clashes, attacks were also supported by state security forces. HRW concluded that the crimes amounted to 'crimes against humanity carried out as part of a campaign of ethnic cleansing.' ${ }^{12}$ In 2014, the UN Special Rapporteur warned that the ongoing human rights violations in Rakhine 'may constitute crimes against humanity'13 The starkest warnings of mass atrocity crimes were

10 By way of example, see an overview of the responses by the Nordic states in Mette Larsen, 'Myanmar Military Coup: Nordic and Asian Reactions', ScandAsia, 2 February 2021, https:// scandasia.com/myanmar-military-coup-nordic-and-asian-reactions/, accessed 16 March 2021.

11 Irish Centre for Human Rights, 'Crimes against Humanity in Western Burma: The Situation of the Rohingyas', 2010.

12 Human Rights Watch, "All You Can Do is Pray": Crimes Against Humanity and Ethnic Cleansing of Rohingya Muslims in Burma's Arakan State', 22 April 2013, https://www.hrw. org/report/2013/04/22/all-you-can-do-pray/crimes-against-humanity-and-ethnic-cleansingrohingya-muslims, accessed 17 March 2021.

13 Tomás Ojea Quintana, Report of the Special Rapporteur on the Situation of Human Rights in Myanmar, A/HRC/25/64, 2 April 2014, para. 51. 
issued in 2015, when several watchdogs warned that there was an imminent risk of genocide against the Rohingya. ${ }^{14}$

At the same time, the field of $\mathrm{R}_{2} \mathrm{P}$ and atrocity prevention seemed to mature. In 2012, the US government established its Atrocity Prevention Board, which as an inter-agency process was meant to increase the government's capacity to detect and respond to atrocity risks. ${ }^{15}$ A growing number of governments had appointed national focal points on $\mathrm{R}_{2} \mathrm{P}$ to facilitate their implementation of the key UN norm on atrocity prevention. ${ }^{16}$ The UN Secretary-General published on 10 August 2017 his ninth report on R2P, titled 'Implementing the Responsibility to Protect: Accountability for Prevention. ${ }^{17}$ Against this background, could there be another instance of unimpeded mass atrocities? Ominously, on the first page of the aforementioned report, the Secretary-General warned that 'there is a gap between our stated commitment to the responsibility to protect and the daily reality confronted by populations exposed to the risk of genocide.' Barely two weeks later, the Myanmar military unleashed horrific violence against the country's Rohingya population. How could the international community and $\mathrm{R}_{2} \mathrm{P}$ fail so miserably?

The research interest underlying the special issue is to identify any lessons that can be learnt that might allow us to strengthen atrocity prevention efforts going forward. This is the more important, as Myanmar today faces new atrocity risks. In addition, it needs to be recalled that the UN Secretary-General commissioned the so-called Rosenthal report to shed light on the UN's role in this failure - while other actors, at least publicly, did not engage in any such exercise. ${ }^{18}$ This is the more striking, as $\mathrm{R}_{2} \mathrm{P}$ concerns the responsibility of states, individually and collectively, and not the role of the UN Secretariat. For

14 Penny Green, Thomas MacManus, and Alicia de la Cour Venning, 'Countdown to Annihilation: Genocide in Myanmar', International State Crime Initiative, September 2015; Alina Lindblom et al., 'Persecution of the Rohingya Muslims: Is Genocide Occurring in Myanmar's Rakhine State? A Legal Analysis', Allard K. Lowenstein International Human Rights Clinic, Yale Law School, October 2015; “They Want Us All to Go Away”: Early Warning Signs of Genocide in Burma', Simon-Skjodt Center for the Prevention of Genocide, United States Holocaust Memorial Museum, May 2015.

15 On the work of the Atrocity Prevention Board see Stephen Pomper, 'Atrocity Prevention under the Obama Administration' in Cecilia Jacob and Martin Mennecke (eds.), Implementing the Responsibility to Protect - A Future Agenda (Milton Park: Routledge, 2020).

16 Martin Mennecke, 'Never Again? The Role of the Global Network of R2P Focal Points in Preventing Atrocity Crimes', Netherlands Human Rights Quarterly, forthcoming.

17 António Guterres, Implementing the Responsibility to Protect: Accountability for Prevention, A/71/1016-S/2017/556, 10 August 2017.

18 Gert Rosenthal, 'A Brief and Independent Inquiry into the Involvement of the United Nations in Myanmar from 2010-2018', 29 May 2019, https://digitallibrary.un.org/ record/38o9543? ln=en, accessed 16 March 2021. 
the future of atrocity prevention - regarding Myanmar and beyond - it seems crucial to examine how it was possible that so many governments and other actors were deeply engaged with Myanmar but ended up as bystanders to what survivors described as what 'felt like the last day of this world'. 19

When the Rohingya militant group Arakan Rohingya Salvation Army (ARSA) attacked a number of Myanmar security posts on 25 August 2017, the retaliation from the Myanmar military came almost immediately and with great brutality. Scores of villages were attacked and destroyed. Thousands of Rohingya men, women, and children were killed, raped, and mutilated. The Myanmar military embarked on the 'unfinished job'20 of removing the Rohingya from Myanmar with negligible resistance from outside actors, including Western countries, UN agencies, and regional powers. Within weeks, several hundreds of thousands of Rohingya had been terrorised to flee across the border into Bangladesh. Although of an unanticipated scale, the events of August 2017 were preceded by decades of repression that increased in severity under the new quasi-civilian government, through military operations, restrictions of basic liberties, and denial of civil and political rights - most notably citizenship.

Among Myanmar's ethnic and religious minorities, many of whom have suffered decades of repression and human rights abuses by the country's military, the Rohingya have been particularly vulnerable, as expressed through their lack of citizenship. In Myanmar, the right to citizenship is based on national ethnic group status and such status is linked to a supposed history of territorial belonging. The official view is that the Rohingya are illegal immigrants from Bangladesh, and the group's long ancestry in Rakhine State is not recognised. ${ }^{21}$ The political reforms after 2011 opened a space for anti-Muslim

19 See UN Independent International Fact-Finding Mission on Myanmar (UnFFMM), Report of the Detailed Findings of the Independent International Fact-Finding Mission on Myanmar, A/HRC/39/CRP.2, 17 September 2018, p. 177 (UNFFMM Report).

20 Senior-General Min Aung Hlaing, on a Facebook post on 2 September 2017 ('Entire government institutions and people must defend the country with strong patriotism') stated that 'The Bengali problem was a long-standing one which has become an unfinished job despite the efforts of the previous governments to solve it. The government in office is taking great care in solving the problem.' His Facebook page is defunct but the post is on file and reported by the Fact-Finding Mission. See UNFFMM Report, p. 180.

21 Nick Cheesman, "How in Myanmar "National Races" Came to Surpass Citizenship and Exclude Rohingya', Journal of Contemporary Asia, 47(3) 461-483 (2017). 
agitation. A general sense of uncertainty fed into narratives of the need to protect Buddhism from Muslim 'threats'. ${ }^{22}$

A dramatic escalation of the crisis came in 2012, when a wave of violence erupted in Rakhine State, and eventually spread beyond Rakhine. More than 140,000 people were displaced in Rakhine State, the vast majority being Rohingya. The displaced Rohingya were placed in what observers have called 'open-air detention facilities', under extremely harsh conditions, and with very limited access to humanitarian aid. ${ }^{23}$ The Rohingya could not participate in the landmark national elections in November 2015. Also in 2015, the 'race and religion laws' promoted by extremist Buddhist monks were enacted by the parliament. ${ }^{24}$ The laws imposed nationwide restrictions on the Rohingya's religious freedom and on their right to marriage and childbirth. This gradual deprivation of rights and worsening of living conditions has led to what some have called a 'slow burning genocide.'25

In 2016, the Myanmar government set up a commission led by former UN Secretary-General Kofi Annan to look into the conflict in Rakhine. However, increased tension, violence, and refugee flows across the Bangladeshi border and deployment of police and military troops to Rakhine during October and November 2016 replaced cautious optimism with renewed fear of escalation. After the violence against the Rohingya and following refugee flow in late 2016, an outspoken UNHCR official warned that 'ethnic cleansing' was taking place. In response to this violence, the UN Human Rights Council set up the Fact-Finding Mission that later came to document the new, massive violence of 2017. In August 2017, just as the Annan commission released its report and recommendations, ARSA launched the aforementioned attacks on outposts of the Myanmar security forces which resulted into the army's 'clearance operations', led by troops that had been deployed to Rakhine in the weeks before 25 August. Since August 2017, land previously owned by Rohingya has been given to non-Rohingya residents in Rakhine, and Rohingya villages have been

22 Matthew J. Walton and Susan Hayward, Contesting Buddhist Narratives: Democratization, Nationalism, and Communal Violence in Myanmar, East-West Center, 2014, https://www. eastwestcenter.org/sites/default/files/private/pso71.pdf, accessed 3 August 2020.

23 Human Rights Watch, "An Open Prison without End": Myanmar's Mass Detention of Rohingya in Rakhine State', 8 October 2020, https://www.hrw.org/report/2020/10/o8/openprison-without-end/myanmars-mass-detention-rohingya-rakhine-state, accessed 17 March 2021.

24 Iselin Frydenlund, 'Religious Liberty for Whom? The Buddhist Politics of Religious Freedom during Myanmar's Transition to Democracy', Nordic Journal of Human Rights, 35(1) 55-73 (2017).

25 Maung Zarni and Alice Cowley, 'The Slow-Burning Genocide of Myanmar's Rohingya', Pacific Rim Law \& Policy Journal, 23(3) 681-752 (2014). 
burned, erased, and renamed. ${ }^{26}$ This not only adds to the list of atrocity crimes, but also makes voluntary return in large numbers from Rohingya refugee camps in Bangladesh to Myanmar almost unthinkable in the foreseeable future.

More than 700,000 Rohingya fled due to so-called 'clearance operations' from Myanmar after August 2017, gathering in what would become one of the world's largest refugee camps in Bangladesh. The biblical proportions of the crisis were evident within weeks, as hundreds of thousands of Rohingya crossed the border to Bangladesh. ${ }^{27}$ However, the degree to which atrocities were carried out in a coordinated and planned manner only became clear with the reports of the UN Fact-Finding Mission established by the Human Rights Council. ${ }^{28}$ Its reports, combined with an investigation by the International Criminal Court (ICC) and proceedings at the International Court of Justice (ICJ), have decidedly shifted the debate on the Rohingya crisis. Among international observers, it is now generally accepted that crimes against humanity perhaps even genocide - have been committed. ${ }^{29}$ However, as was evident in the ICJ proceedings in December 2019, there remains fierce resistance within the Myanmar leadership - including then State Counsellor Aung San Suu Kyi to accept the international account of atrocities, as well as to recognise the Rohingya as a group and part of Myanmar's population.

\section{Atrocity Prevention in an Era of Reform}

After the adoption of a new constitution in 2008, Myanmar has undergone a reform process carefully orchestrated by the country's military that had been in control since 1962. Although falling far short of liberal democratisation, the reforms included an opening of the political space, increased freedoms, and reinstated parliamentary elections - including the 2015 election that placed Aung San Suu Kyi and her National League for Democracy (NLD) party in

26 Poppy McPherson, 'Three Years after Exodus, Myanmar Erases Names of Rohingya Villages, U.N. Map Makers Follow Suit', Reuters, 11 September 2020, https://www.reuters.com/article/ us-myanmar-rohingya-insight-idUSKBN262058, accessed 17 March 2021.

27 'Rohingya Refugee Crisis a “Human Rights Nightmare," UN Chief Tells Security Council', UN News, 28 September 2017, https://news.un.org/en/story/2017/o9/567402-rohingya-refugeecrisis-human-rights-nightmare-un-chief-tells-security-council, accessed 19 March 2021.

28 See the different reports by the UN's Independent International Fact-Finding Mission at https://www.ohchr.org/en/hrbodies/hrc/myanmarffm/pages/index.aspx, accessed 16 March 2021.

29 See the documentation compiled by the UN's Independent International Fact-Finding Mission which is available at https://www.ohchr.org/EN/HRBodies/HRC/MyanmarFFM/ Pages/ReportoftheMyanmarFFM.aspx, accessed 9 March 2021. 
government. The political changes of the reform years serve as a crucial backdrop in understanding international responses to the Rohingya crisis, as these reforms fundamentally altered Myanmar's relations to the outside world.

The transfer of power from the military junta to the nominally civilian government in 2011 marked an important step in the reform process, as did the release of political prisoners and the by-elections in 2012, in which NLD participated and Aung San Suu Kyi won a parliamentary seat. However, parallel to the reforms in Myanmar, human rights abuses against the Rohingya worsened, and the group became increasingly vulnerable to atrocities. In Myanmar, the Rohingya have been perceived as the 'other', the enemy threatening the political entity of Myanmar from within..$^{30}$ The statelessness of the Rohingya is coupled with a notion that their presence in the border territory towards populous and Muslim Bangladesh is a threat to Buddhism. Despite the visible presence of a number of large ethnic and religious minority groups in Myanmar, Buddhism is a defining feature of the Myanmar state, and particularly of the historically strongest state institution, the Myanmar military. The election campaign in 2015 made all these tendencies more salient: it became politically necessary for NLD to distance themselves from Muslims, and the military-backed United Solidarity and Development Party (USDP) rallied on the opportunity to be seen as protectors of Buddhism - and thereby gave the extremist monks a political role and inflated their influence.

Several of the articles in this special issue show that the domestic reform process caused outside actors to be overly optimistic about the path the country was taking. ${ }^{31}$ This optimism diverted attention away from the need to consider and prevent atrocities against the Rohingya. A common theme across several of the articles is the lack of an understanding of the atrocity risks, and lack of institutional mechanisms to identify, analyse, and respond to such risks. Actors did not see the situation in Rakhine State as one of potential atrocity crimes, did not have the analytic tools to distinguish atrocity crimes from armed conflict and general human rights issues, and were prioritising democratisation and economic development in their engagement with Myanmar.

30 Francis Wade, Myanmar's Enemy Within: Buddhist Violence and the Making of a Muslim 'Other' (London: Zed Books, 2017).

31 See the contributions by Cecilia Jacob, 'Navigating between Pragmatism and Principle: Australia's Foreign Policy Response to the 2017 Rohingya Crisis', Ellen E. Stensrud, 'The Rohingya Crsis, the Democratisation Discourse, and the Absence of an Atrocity Prevention Lens', and Kate Ferguson, 'For the Wind is in the Palm-Trees: The 2017 Rohingya Crisis and an Emergent UK Approach to Atrocity Prevention', to this special issue. 
Inside Myanmar, very few actors have openly criticised the military's operations against the Rohingya. With a few notable exceptions, ${ }^{32}$ civil society and political groups that could potentially convey a counter-narrative and be a source of opposition to the military's operations supported the Tatmadaw's rhetoric of counter-terrorism as a response to the ARSA attacks in August 2017. To many Western observers' surprise and disappointment, Nobel laureate and (former) democracy icon Aung San Suu Kyi's reactions to the crisis have mirrored these attitudes. Her denial of the realities of grave human rights abuses against the Rohingya was widely supported in Myanmar - at least until the coup. Despite an increasing support among civil society groups for accountability, as documented in one of the contributions in this special issue, ${ }^{33}$ there are no signs that the attitudes towards the Rohingya among the political leadership will change. The 2020 general elections confirmed the popularity of NLD and Aung San Suu Kyi. The government's denial of fundamental rights to the Rohingya had broad popular support. With the coup, there are signs that at least parts of the anti-coup movement may change their attitude towards the Rohingya - themselves experiencing the brutality of the military first hand. ${ }^{34}$

The effects of the February 2021 coup on the Rohingya's future in Myanmar are highly uncertain at the time of writing. On the one hand, political upheavals such as a coup are a well-known risk factor for mass atrocities. A successful, lasting takeover by the Tatmadaw, the actor who has committed atrocity crimes against the Rohingya, will increase the risk for new violence against the Rohingya, dash any hopes to address the persisting impunity for past atrocities, and add another impediment to the return of those who were forced to flee to Bangladesh. At the same time, there is a visible change of attitude among some of the protesters in the streets of Myanmar. Many express regrets, either though social media or on demonstration posters, that they bought into the military's version of the Rohingya crisis. A crucial determinant in the future of the Rohingya is therefore not only whether the Tatmadaw is able to consolidate its position in the long run, but also whether the aforementioned reactions to the coup attempt by some can generate a change of attitude in the majority population and the NLD leadership towards the ethnic minorities in general and the Rohingya in particular.

32 See Nickey Diamond's contribution, 'The Failure to Protect Rohingya in Myanmar: A Reflection on the National Protection against Mass Atrocity Crimes', to this special issue on Myanmar civil society.

33 ibid.

34 Aakriti Sharma, 'Sorry Rohingyas: Protesters in Myanmar Express Solidarity with Rohingya Muslims after Brutal Army Crackdown', The Eurasian Times, 3 March 2021, https:// eurasiantimes.com/protesters-in-myanmar-solidarity-with-rohingya-muslims/, accessed 17 March 2021. 
In the history of the $\mathrm{R}_{2} \mathrm{P}$ norm since its adoption by the General Assembly at the UN World Summit in $2005,{ }^{35}$ the fate of the Rohingya is one of the most blatant protection failures of the international community. Despite nearly universal commitment to the doctrine as well as a growing number of UN resolutions that make use of $\mathrm{R}_{2} \mathrm{P}$ language, ${ }^{36}$ most international actors avoided political confrontation with Myanmar on the Rohingya issue. In fact, the Rohingya crisis is one of those situations involving the risk of atrocity crimes that has not been addressed in a single Security Council resolution. As one of the contributions in this special issue points out, the confidence that a UN resolution sanctioning use of force would be vetoed by China and Russia has emboldened the Myanmar military in its handling of the Rohingya. ${ }^{37}$ Similarly, there were no international efforts to hold the Tatmadaw accountable for atrocity crimes until after the most recent genocidal campaign against the Rohingya in $2017 \cdot{ }^{38}$ Domestically, the NLD-led government was not able to put constraints on the military actions while in power. Together, there has been a lack of significant $\mathrm{R}_{2} \mathrm{P}$ efforts at all levels, or across all three 'pillars' of $\mathrm{R}_{2} \mathrm{P}$.

UN Secretary-General Ban Ki-moon had specified the relationship between $\mathrm{R}_{2} \mathrm{P}$ and sovereignty through the conceptualisation of a 'three pillars' structure of $\mathrm{R}_{2} \mathrm{P}$ in his report to the General Assembly from 20o9, 'Implementing the Responsibility to Protect'. 39 These pillars were a way to elaborate the different aspects of $\mathrm{R}_{2} \mathrm{P}$ and to answer concerns about sovereignty. The first pillar clarifies that the nation state has the primary responsibility to protect its population against four specific atrocity crimes. The second pillar refers to the international community's responsibility to assist states to protect their own populations, for example through capacity-building. The third pillar refers to the international community's responsibility to act, in a timely and decisive manner, and in accordance with the UN Charter and if necessary by force,

35 '2005 World Summit Outcome', UNGA Res. 6o/1, 16 September 2005.

$3^{6}$ See the lists of resolutions provided by the Global Centre for Responsibility to Protect at https://www.globalr2p.org/resources/un-security-council-resolutions-and-presidentialstatements-referencing-r2p/ (4 January 2021) and https://www.globalr2p.org/resources/ un-human-rights-council-resolutions-referencing-r2p/ (14 September 2020), accessed 24 March 2021.

37 See the contribution to this special issue by Ivan Šimonović, 'Why "Never Again" and R2P Did Not Work in Myanmar'.

$3^{8}$ See in this special issue Sebastiaan Verelst, 'Accountability in Myanmar: A Transformative Stepping-Stone?'.

Ban Ki-moon, Implementing the Responsibility to Protect, A/63/677, 12 January 2009. 
if the relevant state 'manifestly' fails to protect its population. International action by military force is thereby the very last resort and must be authorised by a Chapter viI Security Council resolution. Since the 'last resort' protection by forceful means depends on the Security Council, the doctrine itself builds on the existing system of international law, where sovereignty only loses its shielding function if the Council finds a threat to international peace and security.

In Myanmar, the status of the Rohingya as an extremely vulnerable group worsened during the reform process. As the reforms progressed, hopes for national protection along the first pillar waned. In 2012, the Rohingya became victims of mass atrocities in Rakhine State but were not protected by Burmese security forces. ${ }^{40}$ Rather, Burmese forces were sometimes complicit in the crimes, and more than 120,00o Rohingya were placed in detention camps. In the run-up to the 2015 elections the group was exposed to anti-Muslim campaigns and loss of political rights.

In such a scenario, external actors should in line with pillar 2 have sought to help Myanmar to protect its population from the risk of atrocity crimes. Due to aforementioned focus on the democratic reforms, many actors failed to make a targeted effort to implement pillar 2 or to display even an awareness of such need. ${ }^{41}$ In their cooperation with Myanmar, countries prioritised democratisation, economic development, and political access over a clearer stance on human rights. Simultaneously, China succeeded in renewing its bonds with the Myanmar government, and coordinated international efforts to push the Myanmar government became costly, if not unfeasible. According to the three-pillar structure of $\mathrm{R}_{2} \mathrm{P}$, the lack of national protection should have led other states to actively explore assisting Myanmar in protecting the Rohingya and other groups potentially exposed to atrocity crimes. That did not happen. More than a decade after the adoption of $\mathrm{R}_{2} \mathrm{P}$, its prevention agenda does not yet systematically inform development cooperation and democratisation efforts of states that advocate for the principle. It should also be stressed that pillar 2 requires the consent of the state in question - which made any $\mathrm{R}_{2} \mathrm{P}$ efforts aimed at the protection of the Rohingya difficult, as the Myanmar government denied their existence. ${ }^{42}$

40 Indeed, the UN Fact-Finding Mission highlighted in its report the participation and complicity of government forces in the violence against the Rohingya. See UNFFMM Report, paras. $724-48$.

41 See the contributions of Ferguson and Stensrud to this special issue.

42 On the norm-inherent difficulties of applying $\mathrm{R}_{2} \mathrm{P}$ to Myanmar and together with the government of Myanmar see in this special issue Morten B. Pedersen, "The Rohingya Crisis, Myanmar and R2P "Black Holes". 
With the situation worsening for the Rohingya and in particular after the beginning of the new atrocities on 25 August 2017, the logic of $\mathrm{R}_{2} \mathrm{P}$ stipulates that the international community should exercise its responsibility to enforce protection of the Rohingya through pillar $3 \cdot{ }^{43}$ At this point, however, the $\mathrm{R}_{2} \mathrm{P}$ norm shows its own vulnerability, as the most decisive pillar 3 measures, such as a referral to the ICC or an intervention by force, only can be authorised by the Security Council which in this situation was unrealistic, as China would have vetoed any pillar 3 measures. China's resistance to coordinated action also meant that there was no prospect to adopt an arms embargo or effective global sanctions against those responsible for the atrocities. In addition, regional actors who arguably could have had some influence over Myanmar, such as Indonesia or ASEAN, failed to overcome the principle of non-intervention. ${ }^{44}$ This meant that effective pillar 3 measures to protect the Rohingya from genocidal violence were never on the table. Instead, the focus shifted to humanitarian aid for the survivors of the atrocity crimes and post-facto accountability efforts.

Myanmar thus constitutes a conundrum for $\mathrm{R}_{2} \mathrm{P}$, as its potential as a key norm of atrocity prevention is minimised by the lacking will of the relevant state combined with $\mathrm{R}_{2} \mathrm{P}$ 's reliance on the Security Council which can be obstructed by one or several of its permanent members. Myanmar then, in line with other cases such as North Korea, Syria, and the situation of the Uyghurs in China, showcases that $\mathrm{R}_{2} \mathrm{P}$, including its third pillar, does not provide all the answers to the question of how to prevent or mitigate atrocity crimes in practice. $\mathrm{R}_{2} \mathrm{P}$ has inherent, structural limitations that reflect the compromises that had to be struck at its adoption in 2005 .

Myanmar as an Inevitable Failure of R2P?

The combination of mass atrocities and lack or failure of international intervention has previously led critics to discard $\mathrm{R}_{2} \mathrm{P}$ as dead. ${ }^{45}$ Is Myanmar another example of this narrative? In this context it should be recalled that states that are committed to atrocity prevention previously have devised alternative means, outside the regular $\mathrm{R}_{2} \mathrm{P}$ toolbox, to address relevant situations. In

43 Ban Ki-moon, Implementing the Responsibility to Protect, 2009.

44 See the contributions by Claire Q. Smith and Susannah G. Williams, 'Why Indonesia Adopted "Quiet Diplomacy" over R2P in the Rohingya Crisis: The Roles of Islamic Humanitarianism, Civil-Military Relations, and AsEan', and Noel M. Morada, 'ASEAN and Rakhine Crisis: Balancing Non-Interference, Accountability, and Strategic Interests in Responding to Atrocities in Myanmar', to this special issue.

See David Rieff, 'R2P, R.I.P.', New York Times, 7 November 2011. 
2018, with the UN Security Council being blocked, states decided to establish through a resolution of the UN Human Rights Council an independent, international mechanism to advance the issue of accountability for the atrocities committed against the Rohingya and other groups. Modelled after the mechanism the UN General Assembly had established two years earlier for Syria, the Myanmar Mechanism cannot prosecute those responsible for the atrocities but does compile and process evidence to produce files on individuals that would allow future prosecutions to start as soon as they were politically feasible. ${ }^{46}$ This includes potential new atrocity crimes committed during the military coup. ${ }^{47}$

While these mechanisms cannot, themselves, ensure accountability, they are important new creations from an $\mathrm{R}_{2} \mathrm{P}$ perspective, as they can contribute to protecting the relevant population through trials that may deter further atrocities. According to their mandate, the mechanisms are meant to assist national, regional, or international efforts, but currently they cannot be seen to fall under pillar 2 , as the national governments are not interested in receiving assistance on this kind of accountability, but vehemently opposed to it. Instead, the Mechanisms have started to assist national trials in third states, such as the ones based on the universal jurisdiction principle in Germany. ${ }^{48}$ Thus, the Mechanisms constitute a soft pillar 3 measure, which lack the binding force of a Security Council resolution but benefit from broad international support. They can function without the Council's approval and without the consent of the governments in Syria and Myanmar. They alone, however, are not sufficient when it comes to measuring whether other states and the international community as a whole are living up to their responsibility to protect. This assessment should also be seen as a challenge to researchers and civil society with a focus on $\mathrm{R}_{2} \mathrm{P}$, as there is a need to rethink what it means to apply $\mathrm{R}_{2} \mathrm{P}$ in a situation such as Myanmar, under the given circumstances in the Security Council. ${ }^{49}$

46 On the work and mandate of the Independent Investigative Mechanism for Myanmar see its website at https://iimm.un.org/, accessed 16 March 2021.

47 Independent Investigative Mechanism for Myanmar, 'Recipients of Illegal Orders Should Contact Us', 17 March 2021, https://iimm.un.org/iimm-recipients-of-illegal-orders-shouldcontact-us/, accessed 25 March 2021.

48 On the German efforts to prosecute atrocity crimes in Syria see the information compiled by the European Center for Constitutional and Human Rights at https://www.ecchr.eu/en/ topic/syria/, accessed 16 March 2021.

49 Regarding new approaches on how to implement R2P see the contributions by Camilla Buzzi, 'Mass Atrocities in Myanmar and the Responsibility to Protect in a Digital Age', and Martin Mennecke, 'The International Court of Justice and the Responsibility to Protect: Learning from the Case of The Gambia v. Myanmar', in this special issue. 
The contributions to this special issue critically examine the failure of atrocity prevention in Myanmar and seek to identify lessons and potential avenues going forward for a more effective implementation of $\mathrm{R}_{2} \mathrm{P}^{50}$ The special issue is comprised of three main sections (respectively focusing on the response and role of actors close to Myanmar, Western countries and international law) and concludes with two interventions focused on policy and practice. In the first section, two articles scrutinise the respective role of ASEAN and Indonesia in responding to the Rohingya crisis. This regional angle provides a reality check for the strength of the universal consensus over $\mathrm{R}_{2} \mathrm{P}$ and its three pillars. ${ }^{51}$ The analysis shows that in Southeast Asia the principle of non-intervention still supersedes the commitment to R2P. Domestic factors such as a history of violence, impunity, and international interference further complicates the implementation of $\mathrm{R}_{2} \mathrm{P}$. This regional perspective is important. As the articles on Western actors show, however, the reluctance to prioritise $\mathrm{R}_{2} \mathrm{P}$ over other interests was widely shared among the actors engaged in Myanmar.

In the first article, Noel Morada notes that ASEAN since 2017 has not collectively responded to the Rakhine crisis from the perspective of the $\mathrm{R}_{2} \mathrm{P}$ principle and thus far has failed to put a stop to the atrocities against the Rohingya people in Myanmar. To explain this, Morada points to the group's difficult strategy of balancing three important concerns: 1) its adherence to the non-interference principle; 2 ) the pursuit of justice in the absence of regional accountability mechanisms and sanctions; and 3) ASEAN's strategic interests vis-à-vis China's growing influence in Myanmar. In Morada's analysis, ASEAN is also responding to sustained international pressure in pursuit of justice and accountability, which has led to calls from within the region for the organisation to do more beyond just providing humanitarian assistance to affected communities in Rakhine. Even so, ASEAN consciously avoids pressing too hard on the issue of accountability as this could force Myanmar to totally disengage from ASEAN and also push Myanmar further into China's embrace and thus undermine ASEAN'S strategic interests in the region. The second article in this section, authored by Claire Q. Smith and Susannah Williams, explores

50 Most contributions to the special issue were finalised before the military coup and thus do not reflect any repercussions this new development may have for their analysis.

$5^{1}$ The reference to $\mathrm{R}_{2} \mathrm{P}$ reflecting a universal consensus is an often-cited mantra among the norm's proponents. See Gareth Evans, 'Mass Atrocity Crimes After Syria: The Future of the Responsibility to Protect', 6 November 2013, http://gevans.org/speeches/speech537.html, accessed 17 March 2021. 
the role played by Indonesia. They explain why Indonesia, despite domestic pressure to protect the Rohingya and even to apply $\mathrm{R}_{2} \mathrm{P}$, chose a 'quiet diplomacy' approach. Three factors shaped Indonesia's approach: Islamic humanitarianism, Indonesia's own experience of managing civil - military relations during a contested democratic transition, and its continued commitment to core ASEAN principles. While there was domestic civil society pressure on behalf of the Rohingya's rights - and some of it was successful in increasing humanitarian aid to the Rohingya - other factors restrained the government of Indonesia to put pressure on Myanmar. Looking at Indonesia's own recent political history, Smith and Williams show that the country's experience with international intervention in East Timor, past and ongoing human rights abuses in regions such as Papua, and the impunity of the country's military, influenced the government's policy towards Myanmar. Added to this was the desire not to break with ASEAN's non-intervention line. Together, this led the country to opt for the quiet diplomacy approach.

In the second section of the special issue, the focus is on the response of three Western countries, namely Australia, Norway, and the United Kingdom. All three of them had engaged strongly with Myanmar once the transition towards democracy seemed to be underway. All three are also outspoken supporters of $\mathrm{R}_{2} \mathrm{P}$ and members of the Group of Friends of $\mathrm{R}_{2} \mathrm{P}$ at the United Nations. As the contributions in this section show, each one of these Western countries failed to translate their $\mathrm{R}_{2} \mathrm{P}$ commitment into action when it came to identifying and responding to atrocity risks in Myanmar regarding the Rohingya. A combination of optimism surrounding the reforms and growing political and economic engagements stood in the way of atrocity prevention.

Cecilia Jacob analyses how Australia responded to the threat and commission of atrocity crimes against the Rohingya, which is of particular interest given the country's geographic location and strong profile on $\mathrm{R}_{2} \mathrm{P}$ as one of the co-founders of the Global Network of R2P Focal Points. In Jacob's view, Australia's response to the crisis in Myanmar was mixed: it co-sponsored the Human Rights Council resolution to establish the Independent International Fact-Finding Mission on Myanmar and provided substantial humanitarian aid but has been criticised for not doing enough to pressure the government of Myanmar on the issue, for maintaining defence cooperation with Myanmar throughout the crisis, and for its reluctance to accept Rohingya refugees fleeing the violence. Jacob asks why Australia did not take a more proactive role, and identifies lessons learnt and recommendations to strengthen Australia's atrocity prevention architecture in a way that is consistent with Australia's pragmatic approach to regional assistance and its principled international advocacy. Ellen E. Stensrud examines the role of Norway and looks in particular 
at how the political discourse surrounding the reforms diverted attention away from the need to protect the Rohingya against atrocities. Stensrud addresses the somewhat paradoxical situation that during the reform years in Myanmar, Western optimism about democratisation existed side by side with increasingly dire reports about the human rights abuses against the Rohingya. In order to understand this puzzle, she analyses the Norwegian government's policy shift towards Myanmar, and its deepening engagement up until the landmark 2015 elections. Stensrud argues that the widespread characterisation of the conflict in Rakhine as 'intercommunal', rooted in poverty and underdevelopment in Rakhine State, enabled the narrative of progress and democratisation to be upheld. This prevented actors from seeing the treatment of Rohingya through an 'atrocity prevention lens', and thereby from seeing Myanmar as a case where $\mathrm{R}_{2} \mathrm{P}$ should be applied. Kate Ferguson looks at the United Kingdom which as former colonial power and permanent member of the UN Security Council plays a special role. Her article explores the British government's recent Myanmar policy, its response to the Rohingya crisis of 2017, and the extent to which increasing scrutiny from parliament and civil society in reaction to the atrocities in Rakhine prompted clearer articulation of a national approach to atrocity prevention. The article presents five key failures and argues that a goal for those wishing to preserve and strengthen the principle of $\mathrm{R}_{2} \mathrm{P}$, and advance the goal of preventing mass atrocities, must be to break it free of the UN sphere and integrate the pillars into state structures.

In the third section of the special issue, we turn the focus from the response of different actors to the question of what role international law and its institutions can play in a concrete country situation such as Myanmar to prevent atrocity crimes. The three contributions look respectively at the regulation of social media, the UN Fact-Finding Mission and impunity, and the International Court of Justice. The recent coup by the Tatmadaw illustrates the significance of these issues. Thus, the military takeover shows the horrific effects of impunity on Burmese politics and society, as key military leaders and units have never been held accountable for their role in atrocity crimes against the Rohingya in 2012 and 2017 or those committed against other ethnic minorities. Likewise, the uses of social media by the movement protesting the coup illustrate that these platforms are a double-edged sword.

In the first article of this section, Camilla Buzzi scrutinises need for social media (SoMe) governance to put atrocity prevention at the top of the agenda. As Buzzi argues, liberalisation of the telecommunications sector was a significant part of the political changes that were initiated in 2011 in Myanmar. Smartphones, sim cards, and access to the internet became widely available. Social media platforms, notably Facebook, have emerged as the main access 
to the internet for many people. Buzzi addresses the dilemma that SoMe has become a space both for human rights activism and for inciting human rights abuses against vulnerable minorities. It is well documented that both the state and civil society in Myanmar have used Facebook to foment violence and mass atrocities against the Rohingya and other vulnerable minorities. Buzzi examines challenges for internet and SoMe governance drawing on the response of Facebook and various internet service providers in Myanmar in order to explore how to apply the norm of $\mathrm{R}_{2} \mathrm{P}$ on the net. She thereby provides input for lessons learnt on mass atrocity prevention in a digital age. Next, Sebastiaan Verelst focuses on the significance of impunity for Myanmar, taking departure in the work of the UN Fact-Finding Mission. He argues that the current approach of the international community to the question of accountability for atrocity crimes in Myanmar has done too little to prevent such crimes in the future. Verelst addresses the complex and structural impunity problem that drives the recurrence of atrocity crimes, and argues that the international approach to accountability has failed to respond to this impunity problem. He discusses building blocks for an alternative approach: a deeper understanding of impunity, a multifaceted concept of accountability, a greater awareness of the purpose and limitations of distinct accountability measures, and a deliberate connection between the accountability and prevention agendas. By doing so, Verelst explores how states can more effectively fulfil their international legal obligation to prevent atrocity crimes, in Myanmar and beyond. Thirdly, Martin Mennecke examines the potential of the International Court of Justice for atrocity prevention. He argues that it is a short-sighted to equate accountability in the $\mathrm{R}_{2} \mathrm{P}$ context with a reference to the International Criminal Court - and shows that this is exactly what happens on a regular basis, both in the literature, the annual $\mathrm{R}_{2} \mathrm{P}$ reports issued by the UN Secretary-General, and the subsequent debates in the UN General Assembly. He then refers back to the ICJ's landmark case between Bosnia and Herzegovina and Serbia where the Court in 2007 held that there was a duty to prevent genocide - thus making an important statement on the character and scope of genocide prevention. In light of the new ICJ case which The Gambia in November 2019 started under the UN Genocide Convention against Myanmar, the article analyses the limitations and prospects of the ICJ. Mennecke concludes that this UN Court can make an important and unique contribution to $\mathrm{R}_{2} \mathrm{P}$.

The final academic piece of the special issue is a thought-provoking analysis written by Morten Pedersen who questions whether $\mathrm{R}_{2} \mathrm{P}$ can work in a situation such as Myanmar. While the existing literature on the Rohingya crisis tends to blame specific agents for having failed to fulfil their $\mathrm{R}_{2} \mathrm{P}$ obligations, this article directs our attention to the structural obstacles to mass atrocity 
prevention in Myanmar. Given the high risk of mass atrocities against the Rohingya and low feasibility of effective protection under any of the three pillars of $\mathrm{R}_{2} \mathrm{P}$, Pedersen concludes that it was never plausible that $\mathrm{R}_{2} \mathrm{P}$ could work in this case. The idiom of $\mathrm{R}_{2} \mathrm{P}$ 'black holes' is introduced to denote situations where nothing that can realistically be done within the framework of $\mathrm{R}_{2} \mathrm{P}$ is likely to be sufficient to prevent mass atrocities or protect the victims.

The special issue concludes with a section written by two $\mathrm{R}_{2} \mathrm{P}$ practitioners. Nickey Diamond is a Burmese activist who has followed the domestic debate over Rohingya and R2P. In this contribution, Diamond documents how the international justice mechanisms have helped to garner support among sections of civil society in Myanmar for R2P-related measures. With the coup, domestic attitudes towards $\mathrm{R}_{2} \mathrm{P}$ seem to be changing rapidly although some calls for $\mathrm{R}_{2} \mathrm{P}$ seem to reflect a misplaced hope for a foreign military intervention. In the second, former UN Special Advisor for the Responsibility to Protect Ivan Šimonović reflects on his experience with $\mathrm{R}_{2} \mathrm{P}$ being applied to the Rohingya situation in Myanmar. He looks into reasons for why atrocity prevention failed, pointing, inter alia, to mistakes in reading the situation, but also to a lack of willingness to engage with $\mathrm{R}_{2} \mathrm{P}$ issues both within the UN system and among member states. Šimonović concludes that unless there is political will to tackle the shortcomings identified in the international response to the Rohingya crisis, more failures will follow.

As special editors we are grateful to all our authors for their time and contributions - especially under the difficult circumstances of the COVID-19 pandemic which severely impacted many of us in our capacity to do research and academic writing. We are also thankful for the support provided by the editors of the Global Responsibility to Protect and in particular to Associate Professor Charlie Hunt for his guidance and patience in this process. Finally, we would like to sincerely thank Naomi Kikoler, Stacey May, Audun Aagre, and all the other experts who provided critical commentary and peer reviews and helped to strengthen this special issue. 